\title{
KUALITAS TES ULANGAN AKHIR SEMESTER MATA PELAJARAN MATEMATIKA KELAS VII SEMESTER II SMP NEGERI 12 KENDARI
}

\author{
Nurul Istika ${ }^{\text {I) }}$, Zamsir $^{2)}$, Rahmad Prajono ${ }^{3)}$ \\ ${ }^{1)}$ Alumni Jurusan Pendidikan Matematika, ${ }^{2)}$ Dosen Jurusan Pendidikan Matematika \\ FKIP Universitas Halu Oleo: email: nurulistika2325@ yahoo.com ${ }^{1)}$; \\ zamsir@uho.ac.id ${ }^{2)}$,prajonorahmad@gmail.com ${ }^{2)}$
}

\begin{abstract}
Abstrak
Penelitian ini bertujuan untuk mengetahui: Tingkat kesukaran, daya pembeda, pengecoh, validitas, reliabilitas dan kesalahan baku pengukuran. Hasil analisis diperoleh kesimpulan sebagai berikut: Tingkat kesukaran butir soal tes ulangan akhir semester tidak baik karena perbandingan antara soal mudah, sedang, dan sukar adalah 10\%:60\%:30\%. Bila mengacu standar Depdikbud yaitu 30\%:50\%:20\%. Daya pembeda butir soal tes ulangan akhir semester pada umumnya sudah baik kecuali butir soal nomor 3 dan 30. Pengecoh butir soal tes ulangan akhir semester mata pelajaran pada umumnya sudah berfungsi dengan baik kecuali butir soal nomor:3, 5, 13, 14, 22, dan 29. Validitas butir soal tes ulangan akhir semester pada umumnya sudah baik kecuali butir soal nomor:2, 3, 5, 12, dan 30. Besar reliabilitas tes ulangan akhir semester adalah 0,758 dengan derajat keterandalan kategori tinggi. Besar kesalahan baku pengukuran tes ulangan akhir semester adalah 2.412. Dengan demikian berdasarkan indikator kualitas tes dapat disimpulkan bahwa tes ulangan akhir semester belum berkualitas.
\end{abstract}

Kata kunci: kualitas tes, analisis butir soal, tingkat kesukaran

\section{QUALITY OF REPEATED TEST SUBJECT SEMESTER FINAL GRADE MATH VII SEMESTER II JUNIOR STATE 12 KENDARI}

\begin{abstract}
This research aims to find out: The level of difficulty, distinguishing, humbug, validity, reliability and standard error of measurement. The results of the analysis can be concluded as follows: Level of difficulty test items replay the and of term is not good because a comprasion between a metter of easy, medium and difficult is $10 \%: 60 \%: 30 \%$. When referring to the Department of Education standards are $30 \%: 50 \%: 20 \%$. Distinguishing test items semester final replay in generally good except for item number 3 and 30. Humbug repeat test items semester subjects in general are fungtioning properly except for item numbers: $3,5,13,14,22$, and 29 . The validity of test items semester final replay in generally good except for item numbers: $2,3,5,12$, and 30 of the reliability of the test replicates end of the semester is 0.758 with a high degree of reliability category. Large standard error of measurement repeat the test end of the semester is 2,412. Therefore, based on indicators of the quality of the test can be concluded that the test replicates the end of term of quality yet.
\end{abstract}

Keywords: quality test, analysis of grain problem, difficulty index 


\section{Pendahuluan}

Pendidikan merupakan proses pengubahan sikap dan tata laku seseorang atau kelompok orang dalam usaha mendewasakan manusia melalui upaya pengajaran dan pelatihan. Tujuan pendidikan nasional untuk mengembangkan kemampuan dan membentuk watak serta peradaban bangsa yang bermartabat dalam rangka mencerdaskan kehidupan bangsa. Untuk mencapai tujuan pendidikan nasional, maka salah satu bidang ilmu yang harus dikuasai anak didik adalah bidang matematika. Hal ini beralasan mengingat matematika sebagai salah satu ilmu dasar sekarang ini telah berkembang amat pesat, baik materi maupun kegunaannya. Sebagaimana yang dikemukakan Ruseffendi dalam Sribanung (2002:6). Matematika merupakan ratu dan sekaligus pelayan dari semua ilmu. Dengan demikian, matematika dipandang dapat memberi konstribusi positif terhadap perkembangan ilmu pengetahuan dan teknologi, baik kini maupun masa yang akan datang. Hal ini sejalan dengan yang dikemukakan oleh Henry Sukarman dalam Sukarja (2002:9) "Penguasaan ilmu dan teknologi tak akan tercapai tanpa penguasaan matematika dengan baik".

Pengertian belajar mengajar merupakan suatu sistem yang terdiri atas beberapa komponen yang saling berkaitan dan saling berinteraksi dalam mencapai tujuan. Komponenkomponen tersebut ialah tes, pengukuran, penilaian, dan evaluasi. Kita mungkin tidak asing lagi dengan komponen-komponen tersebut bahkan tidak jarang memang lebih cenderung mengartikan keempat kata tersebut sebagai satu pengertian yang sama sehingga dalam pengucapannya hanya tergantung dari kata mana yang siap untuk diucapkannya. Namun secara konseptual istilah-istilah tersebut berbeda satu sama lain, akan tetapi mempunyai hubungan yang sangat erat.

Menurut Jihad dan Haris (2012:67) mengemukakan bahwa tes merupakan himpunan pertanyaan yang harus dijawab, harus ditanggapi, atau tugas yang harus dilaksanakan oleh orang yang dites. Tes digunakan untuk mengukur sejauh mana seorang siswa telah menguasai pelajaran yang telah disampaikan terutama meliputi aspek pengetahuan dan keterampilan. Sementara itu, Ikhwan (2013) tes adalah cara yang dapat digunakan atau prosedur yang dapat ditempuh dalam rangka pengukuran dan penilaian yang berbentuk pemberian tugas ataupun serangkaian tugas sehingga dapat dihasilkan nilai yang dapat melambangkan prestasi. Sedangkan, Arikunto (2008:32) menjelaskan "tes adalah suatu alat atau prosedur yang sistematis dan obyektif untuk memperoleh data-data atau keterangan-keterangan yang diinginkan tentang seseorang, dengan cara yang tepat dan cepat". Dari keempat pengertian tersebut dapat diartikan tes adalah alat pengukuran yang berupa himpunan pertanyaan yang harus dijawab, harus ditanggapi ataupun tugas yang harus dikerjakan oleh orang yang dites untuk memperoleh data-data atau keterangan-keterangan sehingga dapat dihasilkan nilai yang dapat melambangkan prestasi.

Pengukuran mempunyai arti yang sering dipertukarkan dengan pengertian tes. Hal demikian lazim dikarenakan pemakaian istilah tes dan istilah pengukuran sering kali tidak mengandung perbedaan arti dalam situasi tertentu. Pengukuran adalah suatu proses dimana kita mengunakan angka-angka kepada barang berdasarkan aturan-aturan tertentu (Joni, 1984:7). Secara ringkas Arifin (2009:4) mengemukakan bahwa pengukuran adalah suatu proses atau kegiatan untuk menentukan kuantitas sesuatu. Kata "sesuatu" bisa berarti peserta didik, guru, gedung sekolah, meja belajar, white board, dan lain sebagainya. Dalam proses pengukuran tentu guru harus menggunakan alat ukur (tes atau non-tes). Berdasarkan beberapa pengertian tentang pengukuran yang dikemukakan, dapat dikemukakan bahwa pengukuran adalah suatu proses dimana kita menggunakan angka-angka kepada barang berdasarkan aturan-aturan tertentu atau kegiatan untuk menentukan kuantitas sesuatu. Dalam proses pengukuran, tentu guru harus menggunakan alat ukur (tes atau non-tes).

Penilaian merupakan tindak lanjut dari hasil pengukuran yang telah ada. Depdikbud (dalam Arifin, 2009:4), mengemukakan "penilaian adalah suatu kegiatan untuk memberikan berbagai informasi secara berkesinambungan dan menyeluruh tentang proses dan hasil yang telah dicapai siswa." Kata "menyeluruh" mengandung arti bahwa penilaian tidak hanya diunjukkan pada penguasaan salah satu bidang tertentu saja, tetapi mencakup aspek pengetahuan, keterampilan, sikap, dan nilai- 
nilai. Sementara itu, menurut BSNP (2007), penilaian merupakan serangkaian kegiatan untuk memperoleh, menganalisis, dan menafsirkan data tentang proses dan hasil belajar peserta didik yang dilakukan secara sistematis dan berkesinambungan, sehingga menjadi informasi yang bermakna dalam pengambilan keputusan. Dengan demikian, dapat disimpulkan bahwa penilaian adalah serangkaian kegiatan untuk memperoleh, menganalisis, dan menafsirkan data yang dilakukan secara sistematis dan berkesinambungan untuk mengumpulkan informasi tentang proses dan hasil belajar peserta didik dalam rangka membuat keputusankeputusan berdasarkan kriteria dan pertimbangan tertentu. Jadi, dengan kata lain penilaian adalah memberi penilaian terhadap proses belajar mengajar maupun penilaian hasil belajar siswa, khususnya memberi penilaian tingkah laku, kemampuan siswa dalam pencapaian hasil belajar dalam usaha untuk menentukan mutu atau kualitas dari hasil sesuatu.

Proses belajar mengajar mulai dari tingkat pendidikan dasar sampai pada tingkat perguruan tinggi, setiap tenaga pengajar tidak akan terlepas dari kegiatan evaluasi. Menurut Sudaryono (2012:38) evaluasi (evaluation) merupakan suatu rangkaian kegiatan yang dirancang untuk mengukur efektifitas sistem pembelajaran secara keseluruhan. pada hakikatnya evaluasi adalah suatu proses yang sistematis dan berkelanjutan untuk menentukan kualitas (nilai dan arti) dari sesuatu, berdasarkan pertimbangan dan kriteria tertentu dalam rangka pembuatan keputusan. Sedangkan menurut Ground Lund dalam Lasmi (2011), memandang evaluasi sebagai proses sistematik untuk mengumpulkan, menganalisis serta menafsirkan informasi guna untuk menentukan keberhasilan siswa dalam mencapai kompetensi. Dalam kaitan dengan pembelajaran, data atau informasi itu diperoleh melalui serangkaian kegiatan yang terjadi dalam pembelajaran itu sendiri, seperti apa yang dilakukan dan diperoleh oleh siswa.

Sesuai dengan Undang-Undang Nomor 3 Tahun 2003 tentang Sisdiknas, khususnya BAB XVI tentang evaluasi, dimana pemerintah pusat dan daerah memiliki kewajiban dalam melakukan evaluasi terhadap pengelolah, satuan, jalur, jenjang, jenjang dan jenis pendidikan. Diharapkan, evaluasi tersebut dapat mengendalikan mutu pendidikan secara nasional juga merupakan bentuk akutabilitas pelaksaan pendidikan kepada orang tua (Zamsir \& Hasmawati, 2014). Dalam kegiatan apapun biasanya selalu diadakan kegiatan evaluasi, evaluasi ini dimaksudkan untuk mengetahui sampai sejauh mana keberhasilan yang telah dicapai oleh setiap kegiatan tersebut. Mengetahui keberhasilan guru dalam menyampaikan materi dan sejauh mana siswa dapat menyerap materi tersebut, informasinya dapat diperoleh melalui alat evaluasi yang digunakan. Evaluasi yang dilakukan oleh seorang guru ialah suatu usaha untuk membuat keputusan mengenai keberhasilan proses belajar mengajar, kesiapan belajar dan tercapainya tujuan kurikuler. Hal ini dimaksudkan untuk memperoleh mutu hasil pendidikan di sekolah yang bersangkutan.

Uraian di atas jelas bahwa penyelenggaraan pendidikan di sekolah dituntut dapat menghasilkan peserta didik yang sesuai dengan ukuran (standar) yang ditetapkan secara nasional. Untuk mengetahui sejauh mana ukuran pendidikan telah dicapai melalui program pengajaran di sekolah diperlukan evaluasi atau penilaian pendidikan. Ulangan akhir semester adalah suatu cara yang dianggap akurat untuk mengevaluasi hasil belajar siswa. Soal-soal ulangan akhir semester disusun oleh guru mata pelajaran, yang bertujuan untuk mengevaluasi hasil belajar siswa yang akan mengakhiri semester.

Ada kemungkinan bahwa informasi yang diperoleh dari hasil tes belajar tidak mencerminkan keadaan sebenarnya dari kemampuan siswa. Suatu hasil belajar yang diperoleh dengan menggunakan tes yang kurang baik tentu bukan merupakan cermin yang sebenarnya dari prestasi belajar siswa yang bersangkutan. Mungkin skor dari setiap siswa lebih tinggi atau lebih rendah dari kemampuan siswa sebenarnya. Hasil belajar ini akan memberikan informasi yang keliru mengenai pencapaian hasil belajar siswa. Oleh karena itu, salah satu faktor yang perlu dibenahi adalah menyangkut kualitas tes yang dipergunakan dalam setiap kegiatan.

Ditinjau dari segi penyusunannya tes hasil belajar dapat dibedakan atas dua jenis, yaitu :

(1) Tes baku adalah tes-tes yang sudah sahih (valid) dan andal (reliabel) berdasarkan percobaan terhadap sample-sample yang cukup luas dan representatif, dan (2) Tes buatan guru 
adalah tes yang dibuat oleh guru-guru di sekolah baik secara individual maupun dengan cara bekerja sama dengan sesama guru lain, yang dimana penyusunannya mengikuti teknik dan asas kebenaran dalam arti disesuaikan dengan tujuan dan sasaran khusus dari program atau satuan pelajaran yang telah ditentukan (Ramly, 1997:37). Tes ini biasanya untuk ulangan harian, ulangan pertengahan semester ataupun ulangan akhir semester. Tes ini dimaksudkan untuk mengukur hingga dimana penguasaan murid terhadap materi yang telah diajarkan.

Menurut Suryabrata dalam Jayadi (2005:12), menyatakan suatu tes yang dikatakan baik sebagai alat pengukur harus memenuhi syarat-syarat sebagai berikut: (a) Tes itu harus reliabel, (b) Tes itu harus valid, (c) Tes itu harus diskriminatif, (d) Tes itu harus ekonomis, dan (e) Tes itu harus mudah digunakan. Sedangkan Minaltimay (2010) mengatakan bahwa sebuah tes dikatakan baik jika memenuhi persyaratan: (a) Bersifat valid atau memiliki validitas yang cukup tinggi. Suatu tes dikatakan valid bila tes itu isinya dapat mengukur apa yang seharusnya di ukur, artinya alat ukur yang digunakan tepat. (b) Bersifat reliabel, atau memiliki reliabilitas yang baik. Reliabilitas sering diartikan dengan keterandalan. Suatu tes dikatakan reliabel jika tes itu diberikan berulang-ulang memberikan hasil yang sama. (c) Bersifat praktis atau memiliki kepraktisan. Tes memiliki sifat kepraktisan artinya praktis dari segi perencanaan, pelaksanaan tes dan memiliki nilai ekonomi tetapi harus tetap mempertimbangkan kerahasiaan tes.

Suatu tes dikatakan mempunyai kualitas yang baik apabila tes tersebut memiliki atau memenuhi dua hal, yaitu ketepatan atau validitas dan ketetapan atau reliabilitas (Sudjana dalam Jayadi, 2005:2). Sedangkan menurut Suryabrata dalam Jayadi (2005:2), menyatakan tes yang baik adalah tes yang memenuhi karateristik internal. Adapun yang dimaksud karakteristik internal adalah kualitas soal dari segi kualitatif dan kuantitatif. Kualitas soal dilihat dari segi kualitatif terletak pada kontruksi, segi bahasa dan materi tes tersebut. Analisis secara kualitatif pelaksanaannya menggunakan kaidah yang terdapat pada penulisan tes dan dilakukan sebelum tes itu digunakan atau diujikan. Kualitas soal dilihat dari segi kuantitatif yaitu meliputi taraf kesukaran, daya pembeda, penyebaran jawaban dan reliabilitas tes. Analisis secara kuantitatif pelaksanaanya menggunakan data empirik, data empirik diperoleh dari siswa yang mengerjakan tes. Sedangkan Mudjijo (1995: 72) suatu tes yang berkualitas harus memenuhi syarat-syarat tertentu, diantaranya sebagai berikut: (a) Sahih (valid), yaitu mengukur yang harus diukur sesuai dengan tujuan. (b) Relevan, dalam arti yang diuji sesuai dengan tujuan yang diinginkan. (c) Spesifik, soal yang dapat dijawab hanya oleh peserta didik yang betul-betul belajar dengan rajin. (d) Tidak mengandung ketakasaan (penafsiran ganda). Harus ada patokan. (e) Representatif, soal mewakili materi ajar secara keseluruhan. (f) Seimbang, dalam arti pokok-pokok yang penting diwakili.

Dari beberapa pengertian diatas maka dapat disimpulkan bahwa tes dikatakan memiliki kualitas yang baik apabila memenuhi dua hal, yaitu ketepatan atau validitas dan ketetapan atau reliabilitas serta tes itu sendiri harus memenuhi karakteristik internal, dimana karakteriktis internal yang dimaksud adalah kualitas soal dari segi kualitatif dan kuantitatif.

Berkaitan dengan kriteria kualitas tes yang baik seperti yang disebutkan diatas, soal ulangan akhir semester yang dibuat oleh guru di sekolah pada umumnya belum memenuhi kriteria kualitas soal seperti yang diharapkan. Guru yang sudah berpengalaman mengajar dan menyusun soal-soal tes juga masih sukar menyadari bahwa tes yang dibuatnya masih belum sempurna. Selain itu, juga faktor lain disebabkan oleh karena penyusunan tes ulangan akhir semester yang dibuat guru masih bersifat lokal dan cenderung sifatnya subjektif, dalam arti bahwa baik bentuk maupun konstruksi soalsoalnya sangat tergantung pada guru yang membuatnya. Bahkan tidak jarang soal-soal ulangan akhir semester yang dibuat guru di sekolah dibuat dan dikontruksi secara mendadak tanpa persiapan dan perencanaan yang matang.

Oleh karena itu, kualitas soal yang dibuatnya masih perlu dipertanyakan, apakah sudah memenuhi kriteria sebagai soal yang baik atau belum. Untuk mengetahui tes yang baik tersebut, perlu kiranya dilakukan analisis butir soal, sehingga akan diketahui soal-soal mana yang sudah baik dan soal-soal mana yang masih kurang baik. Jika item-item itu baik, maka dapat dikatakan tesnya juga baik. 
Berdasarkan hasil observasi awal penulis di SMP Negeri 12 Kendari khususnya guru mata pelajaran matematika kelas VII belum pernah melakukan analisis butir soal untuk melihat kualitas soal yang dibuatnya, sehingga belum diketahui bagaimana sesungguhnya kualitas butir soal-soal yang digunakan selama ini, penyebab guru tidak melakukan analisis butir soal antara lain waktu yang tidak memadai dimana guru membuat soal setelah mendapat hasil keputusan rapat sekolah tentang berapa banyak soal dan bentuk tes yang akan diberikan pada siswa saat ulangan akhir semester, rapat sekolah dilaksanakan 2 minggu sebelum ulangan akhir semester dilaksanakan, serta mengingat hasil tes evaluasi hasil belajar yang dilakukan guru di sekolah (soal ulangan harian, soal ulangan tengah semester dan soal ulangan akhir semester) merupakan suatu indikator dari keberhasilan belajar siswa dan keberhasilan guru mengajar di sekolah, maka sangat perlu diketahui sejauh mana kualitas soal yang akan digunakan.

Melihat begitu pentingnya penggunaan nilai ulangan akhir semester, maka salah satu faktor yang perlu dibenahi adalah kualitas tes yang digunakan. Jika kualitas ini baik maka nilai yang diperoleh para peserta tes merupakan gambaran yang sebenarnya tentang kemampuan peserta tes, bukan nilai yang diperoleh secara kebetulan atau untung-untungan semata. Oleh karena itu, perlu dilakukan analisis pada soal ulangan akhir semester yang menjadi salah satu tes hasil belajar, sehingga dapat diketahui butirbutir soal mana yang sudah baik dan yang kurang baik. Analisis butir soal adalah pengkajian pertanyaan agar diperoleh perangkat tes yang memiliki kualitas yang baik. Analisis butir soal bertujuan untuk memperoleh kualitas soal yang baik sehingga dapat memperoleh gambaran tentang prestasi siswa yang sebenarnya (Mudjijo, 1992:135). Sedangkan Sudjana (1992: 135) mengatakan bahwa analisis butir soal bertujuan untuk memperoleh kualitas soal yang baik sehingga dapat memperoleh gambaran tentang prestasi siswa yang sebenarnya. Analisis butir soal ini bukanlah merupakan ciri suatu tes yang baik, melainkan suatu kegiatan yang dapat membantu meningkatkan mutu tes itu sendiri. Pengukuran kualitas tes ulangan akhir semester mata pelajaran matematika khususnya pada kelas VII Semester II di SMP Negeri 12 Kendari digunakan analisis butir soal untuk melihat kualitas tes ulangan akhir semester.

\section{Metode}

Jenis penelitian ini adalah penelitian deskriptif, untuk mengukur kualitas tes ulangan akhir semester mata pelajaran matematika siswa kelas VII Semester II di SMP Negeri 12 Kendari. Populasi dalam penelitian ini adalah semua lembar jawaban siswa kelas VII yang mengikuti ulangan semester II mata pelajaran matematika di SMP Negeri 12 sebanyak 268 lembar jawaban siswa. Sedangkan sampel dalam penelitian ini diambil berdasarkan pendapatnya Arikunto (2008:107) yaitu apabila subjeknya kurang dari seratus maka diambil semua sehingga penelitiannya merupakan penelitian populasi. Selanjutnya jika subjeknya besar (100 ke atas) dapat diambil antara $10-15 \%$ atau 20 $25 \%$. Teknik pengambilan sampel dilakukan secara proporsional random sampling yakni jumlah lembar jawaban siswa setiap kelas diambil 25\%. Oleh karena itu, perincian sampel dalam penelitian ini adalah sebagai berikut:

\section{Tabel 1}

Jumlah Sampel Penelitian

\begin{tabular}{|c|c|c|c|}
\hline No & Kelas & Lembar Jawaban Siswa & Sampel \\
\hline 1 & $\mathrm{VII}_{1}$ & 33 & 8 \\
\hline 2 & $\mathrm{VII}_{2}$ & 33 & 8 \\
\hline 3 & $\mathrm{VII}_{3}$ & 33 & 8 \\
\hline 4 & $\mathrm{VII}_{4}$ & 34 & 9 \\
\hline 5 & $\mathrm{VII}_{5}$ & 34 & 9 \\
\hline 6 & $\mathrm{VII}_{6}$ & 33 & 8 \\
\hline 7 & $\mathrm{VII}_{7}$ & 34 & 9 \\
\hline 8 & $\mathrm{VII}_{8}$ & 34 & 9 \\
\hline \multicolumn{2}{|r|}{ Jumlah } & 268 & 68 \\
\hline
\end{tabular}


Teknik pengumpulan data yang digunakan dalam penelitian ini adalah teknik dokumentasi, yaitu mengambil soal-soal ulangan

dan lembar jawaban peserta. Sumber data peneliti diperoleh dari dokumen sekolah, dalam penelitian ini adalah di SMP Negeri 12 Kendari.

Teknik yang digunakan untuk mengolah data hasil penelitian ini yaitu dengan menggunakan program ITEMAN versi 3,00. Dalam hal ini menganalisis data, meliputi tingkat kesukaran, daya pembeda, pengecoh atau distraktor, validitas, reliabilitas, dan kesalahan baku pengukuran.

\section{Tingkat Kesukaran}

Rumus yang digunakan untuk mencari tingkat kesukaran adalah:

$$
P=\frac{B}{J S}
$$

(Arikunto, 2008: 208)

Di mana:

$\mathrm{P}=$ Indeks kesukaran soal

$\mathrm{B}=$ Banyaknya siswa yang menjawab dengan benar

$\mathrm{JS}=$ Jumlah siswa peserta tes

Untuk menafsirkan tingkat kesukaran soal diklasifikasikan sebagai berikut:
$0,00 \leq \mathrm{TK} \leq 0,30 \quad$ : Sukar
$0,31 \leq \mathrm{TK} \leq 0,70 \quad:$ Sedang
$0,71 \leq \mathrm{TK} \leq 1,00 \quad:$ Mudah

(Arikunto, 2008: 210)

\section{Daya Pembeda}

Rumus yang digunakan untuk menghitung daya pembeda adalah:

$$
D=\frac{B A}{J A}-\frac{B B}{J B}=P A-P B
$$

(Arikunto, 2008: 213-

Di mana:

$\mathrm{D}$ = Daya pembeda

PA = Proporsi peserta kelompok atas yang menjawab benar

$\mathrm{PB}=$ Proporsi peserta kelompok bawah yang menjawab benar

$\mathrm{JA}=$ Banyak peserta kelompok atas akhir semester, semester II mata pelajaran matematika kelas VII,

$$
\mathrm{JB}=\text { Banyak peserta kelompok }
$$
bawah

$\mathrm{BA}=$ Banyaknya peserta kelompok atas yang menjawab soal dengan benar

$\mathrm{BA}=$ Banyaknya peserta kelompok bawah yang menjawab soal dengan benar

Kriteria penafsiran daya pembeda suatu butir soal diklasifikasikan sebagai berikut:

$$
\begin{array}{ll}
D<0,00 & : \text { Jelek sekali } \\
0,00 \leq D<0,20 & : \text { Jelek } \\
0,21 \leq D<0,40 & : \text { Cukup } \\
0,41 \leq D<0,70 & : \text { Baik } \\
0,71 \leq D \leq 1,00 & \text { : Baik sekali }
\end{array}
$$

$D$ : negatif, semuanya tidak baik, jadi semua butir soal yang mempunyai nilai $\mathrm{D}$ negatif sebaiknya dibuang saja. (Arikunto, 2008:218)

\section{Pengecoh}

Untuk menentukan berfungsi tidaknya pengecoh, dipakai ketentuan bahwa suatu pengecoh dapat berfungsi dengan baik, jika paling sedikit dipilih oleh $5 \%$ pengikut tes (Arikunto, 2008:220). Kegunaan pengecoh adalah untuk melihat seberapa jauh option pengecoh dapat mengecoh siswa untuk tidak memilih kunci jawaban. Dalam penelitian ini untuk menghitung pengecoh peneliti menggunakan program ITEMAN versi 3,00, indeks pengecoh dapat dilihat pada hasil ITEMAN Prop Endorsing. Jika responden yang memilih kurang dari 5\% maka pengecoh tersebut tidak berfungsi dengan baik.

\section{Validitas}

Validitas item dihitung dengan rumus point biserial:

$$
\gamma_{p b i}=\frac{M_{p}-M_{t}}{S_{t}} \sqrt{\frac{p}{q}}
$$

(Arikunto, 2008: 72)

Di mana:

$$
\gamma_{p b i}=\text { Koefisien korelasi biserial }
$$


menjawab benar

$$
\begin{aligned}
M_{p} & =\text { Rerata skor dari subyek yang } \\
& \text { menjawab benar bagi item yang } \\
& \text { dicari validitasnya } \\
M_{t} & =\text { Rerata skor total } \\
S_{t} & =\text { Standar deviasi dari skor total } \\
\mathrm{p} & =\text { Proporsi siswa yang }
\end{aligned}
$$

$(p=$

$\frac{\text { Banyaknya siswa yang menjawab benar }}{\text { Jumla } h \text { seluru } h \text { siswa }}$

$\mathrm{q}=$ Proporsi siswa yang

menjawab salah $(q=1-p)$ berikut :

Adapun kriteria pengujian sebagai

a) Jika $\gamma_{p b i} \geq r_{\text {tabel }}$ dengan $\alpha=0,05$ maka item tersebut valid

b) Jika $\gamma_{p b i}<r_{\text {tabel }}$ dengan $\alpha=0,05$ maka item tersebut tidak valid.

\section{Reliabilitas}

Untuk menentukan tingkat reliabilitas tes soal pilihan ganda menggunakan rumus Kuder- Richadson- 20 (KR-20).

$$
r_{11}=\left(\frac{n}{n-1}\right)\left(\frac{s^{2}-\sum p q}{s^{2}}\right)
$$

(Arikunto, 2008: 100-

Di mana:

$$
\begin{aligned}
& r_{11}=\text { Reliabilitas tes secara } \\
& \text { keseluruhan } \\
& \mathrm{n}=\text { Banyaknya item } \\
& \mathrm{p}=\text { Proporsi subjek yang } \\
& \text { menjawab item dengan benar } \\
& \mathrm{q}=\text { Proporsi subjek yang } \\
& \text { menjawab item dengan salah }(\mathrm{q}=1- \\
& \mathrm{p}) \\
& \sum p q=\text { Jumlah hasil perkalian antara } \\
& \mathrm{S} \quad \text { p dan } \mathrm{q} \\
&
\end{aligned}
$$

Kriteria yang digunakan untuk menafsirkan reliabilitas tes diklasifikasikan sebagai berikut:

$\begin{array}{ll}r_{11} \leq 0,20 & \text { reliabilitas } \\ \text { sangat rendah } & \text { : } \\ 0,21<r_{11} \leq 0,40 & \text { reliabilitas } \\ \text { rendah } & \text { : }\end{array}$

$$
\begin{array}{lc}
0,41<r_{11} \leq 0,70 & \text { reliabilitas : } \\
\text { sedang } & \\
0,71<r_{11} \leq 0,90 & \text { reliabilitas : } \\
\text { tinggi } & \text { reliabilitas : } \\
\text { sangat tinggi } & \text { (Guilford dalam Jihad dan Hariz, }
\end{array}
$$

Dalam penelitian ini suatu tes dikatakan mempunyai reliabilitas yang baik apabila minimal mempunyai reliabilitas sedang $\left(\mathrm{r}_{11}=\right.$ $0,40)$.

\section{Kesalahan Baku Pengukuran}

Adapun rumus yang digunakan adalah:

Di mana:

$$
K B P=S D_{x} \sqrt{1-r_{11}}
$$

$$
\begin{aligned}
& K B P=\text { Kesalahan baku } \\
& \text { pengukuran } \\
& \begin{array}{l}
S D_{x}=\text { Simpangan baku } \\
(\text { standar deviasi) }
\end{array} \\
& r_{11}=\text { Koefisien reliabilitas }
\end{aligned}
$$

(Safari,

1993:128)

\section{Hasil}

Secara kuantitatif, hasil analisis soal tes ulangan akhir semester mata pelajaran matematika siswa kelas VII semester II di SMP Negeri 12 Kendari dapat diketahui dengan menggunakan program ITEMAN versi 3,00. Hasil penelitian yang dapat diketahui meliputi indeks tingkat kesukaran, daya pembeda, efektifitas pengecoh, validitas, reliabilitas, dan kesalahan baku pengukuran. Berdasarkan analisis program iteman, tingkat kesukaran soal ditunjukkan oleh prop correct, daya pembeda soal dilihat pada biser, pengecoh atau distraktor pada prop endorsing, validitas pada point biser, reliabilitas tes pada koefisien alpha, dan kesalahan baku pengukuran ditunjukkan oleh Standar Error of Measurement / SEM. Hasil penelitian dan analisis selengkapnya dapat dilihat pada sajian berikut:

\section{Tingkat Kesukaran}

Tingkat kesukaran soal tes ulangan akhir semester mata pelajaran matematika siswa kelas VII semester II di SMP Negeri 12 
Kendari dikelompokkan dalam 3 kategori yaitu : mudah, sedang, dan sukar. Selengkapnya, tingkat kesukaran soal tes ulangan akhir semester mata pelajaran matematika siswa kelas VII semester II di SMP Negeri 12 Kendari menurut kategori mudah, sedang, dan sukar dengan menggunakan program ITEMAN versi 3.00, dapat dilihat pada Tabel 2 berikut:

Tabel 2

Tingkat Kesukaran Tes Ulangan Akhir Semester Mata Pelajaran Matematika Siswa Kelas VII Semester II di SMP Negeri 12 Kendari

\begin{tabular}{|c|c|c|c|c|c|}
\hline No & $\begin{array}{c}\text { Interval Indeks } \\
\text { Kesukaran }\end{array}$ & Jumlah & Persentase & Nomor Butir & $\begin{array}{c}\text { Kategori } \\
\text { Soal }\end{array}$ \\
\hline 1 & $0,00 \leq T K \leq 0,30$ & 9 & 30 & $4,8,12,14,17,19,20,26,30$ & Sukar \\
\hline 2 & $0,31 \leq T K \leq 0,70$ & 18 & 60 & $\begin{array}{l}2,3,5,6,7,9,10,11,13,15, \\
16,18,21,23,25,27,28,29\end{array}$ & Sedang \\
\hline 3 & $0,71 \leq T K \leq 1,00$ & 3 & 10 & $1,22,24$ & Mudah \\
\hline \multicolumn{2}{|l|}{ Jumlah } & 30 & 100 & & \\
\hline
\end{tabular}

Tabel diatas menunjukkan tingkat kesukaran setiap butir soal tes ulangan akhir semester mata pelajaran matematika siswa kelas VII Semester II diperoleh sebanyak 18 butir soal $(60 \%)$ termasuk soal-soal sedang, 9 butir soal (30\%) termasuk soal-soal sukar, dan 3 butir soal $(10 \%)$ termasuk soal-soal mudah. Dapat dituliskan perbandingan persentase tingkat kesukaran butir soal berdasarkan hasil perhitungan dengan kategori soal mudah, sedang, dan sukar masing-masing adalah 10\%: $60 \%: 30 \%$.
Daya pembeda soal tes ulangan akhir semester mata pelajaran matematika siswa kelas VII semester II di SMP Negeri 12 Kendari dikelompokkan ke dalam lima kategori, yakni: jelek sekali, jelek, cukup, baik dan baik sekali. Selengkapnya, daya pembeda soal tes ulangan akhir semester mata pelajaran matematika siswa kelas VII semester II di SMP Negeri 12 Kendari menurut kategori jelek sekali, jelek, cukup, baik, dan baik sekali dengan menggunakan program ITEMAN versi 3.00, dapat dilihat pada Tabel 3 berikut:

\section{Daya Pembeda}

Tabel 3

Daya Pembeda Soal Tes Ulangan Akhir Semester Mata Pelajaran Matematika Siswa Kelas VII Semester II di SMP Negeri 12 Kendari

\begin{tabular}{|c|c|c|c|c|c|}
\hline No & $\begin{array}{c}\text { Interval Indeks } \\
\text { Daya Pembeda }\end{array}$ & Jumlah & Persentase & Nomor Butir & $\begin{array}{c}\text { Kategori } \\
\text { Soal }\end{array}$ \\
\hline 1 & $D<0,00$ & - & - & \multicolumn{1}{|c|}{-} & Jelek Sekali \\
\hline 2 & $0,00 \leq D<0,20$ & 2 & 7 & 3,30 & Jelek \\
\hline 3 & $0,21 \leq D<0,40$ & 9 & 30 & $\begin{array}{l}2,5,12,15,17,18,20,23, \\
25\end{array}$ & Cukup \\
\hline 4 & $0,41 \leq D<0,70$ & 17 & 56 & $\begin{array}{l}4,6,7,8,9,10,11,13,14, \\
16,21,22,24,26,27,28,29\end{array}$ & Baik \\
\hline 5 & $0,71 \leq D \leq 1,00$ & 2 & 7 & 1,19 & Baik Sekali \\
\hline & Jumlah & 30 & 100 & & \\
\hline
\end{tabular}

Tabel diatas menunjukkan daya pembeda setiap butir soal tes ulangan akhir semester mata pelajaran matematika siswa kelas VII Semester II diperoleh sebanyak 2 butir soal (7\%) mempunyai daya pembeda baik sekali, 17 butir soal (56\%) mempunyai daya pembeda baik, 9 butir soal (30\%) mempunyai daya pembeda cukup, 2 butir soal (7\%) mempunyai daya pembeda jelek, dan tidak ada daya pembeda jelek sekali.

\section{Pengecoh}

Pengecoh soal tes ulangan akhir semester mata pelajaran matematika siswa kelas VII semester II di SMP Negeri 12 
Kendari dikelompokkan dalam dua bagian, yakni pengecoh yang berfungsi dengan baik dan pengecoh yang belum berfungsi dengan baik. Selengkapnya, pengecoh soal tes ulangan akhir semester mata pelajaran matematika siswa kelas VII semester II di SMP Negeri 12
Kendari menurut kategori pengecoh yang berfungsi dengan baik dan pengecoh yang belum berfungsi dengan baik dengan menggunakan program ITEMAN versi 3.00, dapat dilihat pada Tabel 4 berikut:

Tabel 4

Pengecoh Soal Tes Ulangan Akhir Semester Mata Pelajaran Matematika Siswa Kelas VII Semester II di SMP Negeri 12 Kendari

\begin{tabular}{|c|c|c|c|}
\hline Kategori Soal & Nomor Butir & Jumlah & Persentase \\
\hline $\begin{array}{c}\text { Baik } \\
\text { (Efektif) }\end{array}$ & $\begin{array}{c}1,2,4,6,7,8,9,10,11,12,15,16,17, \\
18,19,20,21,23,24,25,26,27,28,30\end{array}$ & 24 & 80 \\
\hline $\begin{array}{c}\text { Revisi } \\
\text { (Tidak efektif) }\end{array}$ & $3,5,13,14,22,29$ & 6 & 20 \\
\hline \multicolumn{2}{|c|}{ Jumlah } & 30 & 100 \\
\hline
\end{tabular}

Tabel diatas menunjukkan pengecoh setiap butir soal tes ulangan akhir semester mata pelajaran matematika siswa kelas VII Semester II terlihat bahwa 6 butir soal tes ulangan akhir semester mata pelajaran matematika siswa kelas VII semester II di SMP Negeri 12 Kendari yang belum berfungsi dengan baik dan 24 butir soal tes ulangan akhir semester mata pelajaran matematika siswa kelas VII semester II di SMP Negeri 12 Kendari yang berfungsi dengan baik.

\section{Validitas}

Validitas soal tes ulangan akhir semester mata pelajaran matematika siswa kelas VII semester II di SMP Negeri 12 Kendari dikelompokkan kedalam dua kategori, yakni valid dan tidak valid. Selengkapnya, validitas soal tes ulangan akhir semester mata pelajaran matematika kelas VII semester II di SMP Negeri 12 Kendari menurut kategori valid dan tidak valid, dapat dilihat pada Tabel berikut:

Tabel 5

Validitas Soal Tes Ulangan Akhir Semester Mata Pelajaran Matematika Siswa Kelas VII Semester II di SMP Negeri 12 Kendari

\begin{tabular}{|c|c|c|c|c|}
\hline No & Keterangan & Nomor Butir & Jumlah & Persentase \\
\hline 1 & Valid & $\begin{array}{c}1,4,6,7,8,9,10,11,13,14,15,16,17,18, \\
19,20,21,22,23,24,25,26,27,28,29\end{array}$ & 25 & 83 \\
\hline 2 & Tidak Valid & $2,3,5,12,30$ & 5 & 17 \\
\hline \multicolumn{2}{|c|}{ Jumlah } & 30 & 100 \\
\hline
\end{tabular}

Tabel diatas menunjukkan validitas setiap butir soal tes ulangan akhir semester mata pelajaran matematika siswa kelas VII semester II terlihat bahwa 5 butir soal tes ulangan akhir semester mata pelajaran matematika siswa kelas VII semester II di SMP Negeri 12 Kendari yang termasuk dalam kategori tidak valid dan 25 butir soal tes ulangan akhir semester mata pelajaran matematika siswa kelas VII semester II di SMP Negeri 12 Kendari yang termasuk dalam kategori valid.

\section{Reliabilitas}

Berdasarkan hasil perhitungan yang diketahui dengan menggunakan program ITEMAN versi 3.00, diperoleh reliabilitas tes ulangan akhir semester mata pelajaran matematika siswa kelas VII semester II di SMP Negeri 12 Kendari sebesar 0,758 dilihat dari koefisien alpha, berdasarkan kriteria Guilford (dalam Jihad dan Hariz, 2012:181) terletak pada interval $0,71<r_{11} \leq 0,90$ berarti data tersebut menunjukkan reliabilitas tes ulangan akhir semester mata pelajaran matematika siswa kelas VII semester II yang masuk dalam kategori tinggi. 


\section{Jurnal Penelitian Pendididikan Matematika Volume 7 No.2 Mei 2019}

\section{Kesalahan Baku Pengukuran}

Berdasarkan hasil perhitungan yang diketahui dengan menggunakan program ITEMAN versi 3.00, diperoleh kesalahan baku pengukuran tes ulangan akhir semester mata pelajaran matematika siswa kelas VII semester II di SMP Negeri 12 Kendari sebesar 2.412 dilihat dari koefisien SEM.

Berdasarkan indikator tingkat kesukaran, daya pembeda, pengecoh atau distraktor, validitas, dan reliabilitas tes ulangan akhir semester mata pelajaran matematika siswa kelas VII semester II di SMP Negeri 12 Kendari maka disimpulkan bahwa tes ulangan tersebut belum berkualitas. Namun demikian secara terpisah dilihat dari masing-masing indikator maka ditemukan bahwa dari segi daya pembeda, pengecoh atau distraktor, validitas, dan reliabilitas tes pada umumnya sudah berfungsi dengan baik, dengan kesalahan baku pengukuran sebesar 2.412 .

\section{Pembahasan}

Dilihat dari hasil penelitian maka akan dibahas secara mendalam pada pembahasan mengenai tingkat kesukaran, daya pembeda, pengecoh, validitas, reliabilitas, dan kesalahan baku pengukuran.

Tingkat kesukaran soal adalah perbandingan antara banyaknya peserta tes yang menjawab dengan benar dengan jumlah peserta tes secara keseluruhan. Tingkat kesukaran ini mengambarkan kemampuan siswa menjawab soal yang diberikan. Berdasarkan hasil analisis dari 30 butir soal terdapat sebanyak 18 butir soal $(60 \%)$ termasuk soal-soal sedang, 9 butir soal $(30 \%)$ termasuk soal-soal sukar, dan 3 butir soal $(10 \%)$ termasuk soal-soal mudah. Butir soal berkategori sukar memiliki kriteria kesukaran dari $0,00 \leq \mathrm{TK} \leq 0,30$, butir soal sedang memiliki kriteria kesukaran dari $0,31 \leq \mathrm{TK} \leq$ 0,70 , dan butir soal mudah memiliki kriteria kesukaran dari $0,71 \leq \mathrm{TK} \leq 1,00$.

Tingkat kesukaran butir soal yang diteliti termaksud kurang baik, karena tidak sesuai dengan petunjuk penulisan butir soal yang baik menurut Depdikbud dalam Jayadi (2005:25), yaitu dalam setiap perangkat soal tes harus memuat $30 \%$ soal mudah, $50 \%$ soal sedang, dan $20 \%$ soal sukar, atau dengan perbandingan tingkat kesukaran soal tes untuk ketiga kategori mudah, sedang, dan sukar adalah $3: 5: 2$, dengan kata lain apabila jumlah soal tes 30 butir soal maka sebaiknya terdiri dari 9 soal mudah, 15 soal sedang, dan 6 soal sukar.

Secara keseluruhan dari hasil analisis butir soal maka dapat disimpulkan bahwa soal tes ulangan akhir semester mata pelajaran matematika siswa kelas VII semester II di SMP Negeri 12 Kendari mempunyai tingkat kesukaran yang sukar untuk dijawab oleh peserta tes sehingga pengukuran tidak maksimal. Ketika seluruh peserta tes menjawab salah pada butir soal atau bahkan seluruhnya menjawab dengan benar, maka ada kecendrungan soal tersebut tidak baik untuk digunakan. Sehingga sangat diharapkan dalam pembuatan soal tes selanjutnya tingkat kemampuan siswa perlu diperhatikan oleh setiap guru dimana soal yang dibuat tidak terlalu sukar dan harus memenuhi petunjuk penulisan butir soal tes yang baik.

Dapat disimpulkan bahwa tingkat kesukaran butir soal tes ulangan akhir semester mata pelajaran matematika siswa kelas VII semester II di SMP Negeri 12 Kendari tidak baik karena tidak mengacu pada standar yang ditetapkan Depdikbud yaitu 3: $5: 2$ atau 30\%: $50 \%: 20 \%$.

Daya pembeda soal adalah kemampuan suatu soal dalam membedakan antara siswa yang berkemampuan tinggi dengan siswa yang berkemampuan rendah. Berdasarkan hasil analisis dari 30 butir soal hanya ada 2 butir soal (7\%) mempunyai daya pembeda baik sekali, 17 butir soal (56\%) mempunyai daya pembeda baik, 9 butir soal $(30 \%)$ mempunyai daya pembeda cukup, 2 butir soal (7\%) mempunyai daya pembeda jelek, dan 0 butir soal $(0 \%)$ mempunyai daya pembeda jelek sekali.

Butir soal yang baik adalah yang dapat membedakan antara kelompok berkemampuan tinggi dan berkemampuan rendah dengan layak. Artinya, butir soal yang dapat dijawab dengan benar oleh siswa yang berkemampuan tinggi maupun siswa yang berkemampuan rendah, maka butir soal tersebut tidak baik karena tidak mempunyai daya pembeda. Butir soal yang mempunyai daya pembeda yang baik berarti butir soal tersebut dapat dijawab lebih banyak oleh siswa yang berkemampuan tinggi. Daya pembeda tidak baik disebabkan 
oleh indeks kesulitan yang terlalu rendah atau terlalu tinggi. Butir soal yang terlalu sulit atau terlalu mudah tidak dapat membedakan antara siswa yang berkemampuan tinggi dengan siswa yang berkemampuan rendah sehingga tidak mempunyai daya pembeda yang baik rendahnya daya pembeda juga dipengaruhi oleh faktor distraktor (pengecoh). Pengecoh dikatakan efektif bila dipilih oleh peserta tes yang berasal dari bawah, sebaliknya apabila pengecoh tersebut dipilih oleh peserta tes dari kelompok atas, berarti pengecoh tersebut tidak berfungsi sebagaimana mestinya. Dengan kata lain, butir soal tes tersebut tidak dapat membedakan antara siswa berkemampuan tinggi dan berkemampuan rendah. Agar daya pembeda baik, penulis soal juga perlu memperhatikan keefektifitas distraktor.

Berdasarkan hasil analisis daya pembeda, bahwa soal nomor: 3, dan 30 merupakan soal yang jelek, karena soal ini tidak dapat membedakan antara siswa yang berkemampuan tinggi dengan siswa yang berkemampuan rendah, soal seperti ini sebaiknya disisihkan atau direvisi secara total. Maka dapat disimpulkan bahwa daya pembeda soal tes ulangan akhir semester mata pelajaran matematika siswa kelas VII semester II di SMP Negeri 12 Kendari pada umumnya sudah baik, akan tetapi terdapat $7 \%$ soal yang mempunyai daya pembeda kurang baik dan perlu dilakukan direvisi.

Dilihat dari pengecoh soal, ditemukan sebanyak 24 butir soal (80\%) pengecohnya berfungsi dengan baik dan 6 butir soal (20\%) pengecohnya belum berfungsi dengan baik. Nomor butir yang pengecohnya berfungsi dengan baik adalah nomor: 1, 2, 4, $6,7,8,9,10,11,12,15,16,17,18,19,20$, $21,23,24,25,26,27,28$, dan 30 . Sedangkan nomor butir soal yang pengecohnya belum berfungsi dengan baik yaitu nomor: 3 (Pengecoh D), 5 (Pengecoh A), 13 (Pengecoh A), 14 (Pengecoh D), 22 (Pengecoh A), dan 29 (Pengecoh D). Pengecoh ini tidak berfungsi dengan baik karena dipilih kurang dari $5 \%$ peserta tes.
Penyebab dipilihnya kurang dari 5\%, kerena pengecoh tersebut terlihat tidak menarik untuk dipilih para peserta tes. Seperti pada soal tes nomor 3 dimana option A. -35 , option B. -25 , option C. 25 , dan option D. 55. Akan lebih baik jika option D itu diganti, dilihat dari pengurutan angka sebaiknya option D itu diganti dengan 35, karena untuk option 55 itu terlalu melonjak atau menyimpang bila dibandingankan dengan option A, B, dan C. Apabila angka tersebut diganti maka ada kemungkinan option D nomor 3 akan berfungsi, karena option terlihat lebih menarik untuk dipilih para peserta tes. Begitu pula untuk 5 (Pengecoh A), 13 (Pengecoh A), 14 (Pengecoh D), 22 (Pengecoh A), dan 29 (Pengecoh D) sebaiknya diganti karena terlihat tidak menarik untuk dipilih para peserta tes.

Dapat disimpulkan bahwa secara umum pengecoh soal pada tes ulangan akhir semester mata pelajaran matematika siswa kelas VII semester II di SMP Negeri 12 Kendari sudah berfungsi dengan baik, akan tetapi terdapat $20 \%$ soal yang mempunyai pengecoh yang belum berfungsi dengan baik.

Hasil analisis dari segi validitas soal, ditemukan sebanyak 25 butir soal (83\%) yang termasuk dalam kategori valid yaitu nomor: $1,4,6,7,8,9,10,11,13,14,15,16$, $17,18,19,20,21,22,23,24,25,26,27,28$, dan 29 serta 5 butir soal (17\%) yang termasuk dalam kategori tidak valid yaitu nomor: 2, 3, 5, 12, dan 30. Dapat disimpulkan bahwa secara umum validitas soal pada tes ulangan akhir semester mata pelajaran matematika siswa kelas VII semester II di SMP Negeri 12 Kendari sudah berfungsi dengan baik, akan tetapi terdapat $17 \%$ soal yang masih dikategorikan belum valid.

Hasil analisis dari segi reliabilias tes yang diketahui dari koefisien alpha dalam program ITEMAN versi 3,00 menunjukkan bahwa reliabilitas tes ulangan akhir semester mata pelajaran matematika siswa kelas VII semester II di SMP Negeri 12 Kendari 
sebesar 0,758. Dengan demikian, reliabilitas tes ulangan akhir semester mata pelajaran matematika siswa kelas VII semester II di SMP Negeri 12 Kendari dapat dikatakan tinggi. Besarnya alpha yang dinyatakan baik bila berada pada kisaran $0,40-1,00$. Nilai alpha 0,758 menyatakan kualitas tes tersebut baik dan dikategorikan sebagai soal yang layak (tinggi) akan tetapi masih perlu adanya perbaikan, baik itu tingkat kesukaran soal, daya pembeda soal, dan keefekifan distraktor sebagai pengecoh jawaban.

Hasil analisis dari segi kesalahan baku pengukuran tes yang diketahui dari koefisien SEM dalam program ITEMAN versi 3,00 menunjukkan bahwa kesalahan baku pengukuran tes ulangan akhir semester mata pelajaran matematika siswa kelas VII semester II di SMP Negeri 12 Kendari sebesar 2,412. Terjadinya kesalahan baku pengukuran disebabkan karena adanya jawaban siswa yang bervariasi (heterogen) yakni jawaban setiap siswa yang menjawab tes tersebut berbeda.

Berdasarkan indikator tingkat kesukaran, daya pembeda, pengecoh atau distraktor, validitas, dan reliabilitas tes ulangan akhir semester mata pelajaran matematika siswa kelas VII semester II di SMP Negeri 12 Kendari maka disimpulkan bahwa tes ulangan tersebut belum berkualitas. Namun demikian secara terpisah dilihat dari masing-masing indikator maka ditemukan bahwa dari segi daya pembeda, pengecoh atau distraktor, validitas, dan reliabilitas tes pada umumnya sudah berfungsi dengan baik. Namun dilihat dari indikator tingkat kesukaran butir soal tidak baik.

Berdasarkan indikator tingkat kesukaran, daya pembeda, pengecoh atau distraktor, validitas, dan reliabilitas tes ulangan akhir semester mata pelajaran matematika siswa kelas VII semester II di SMP Negeri 12 Kendari maka disimpulkan bahwa tes ulangan tersebut belum berkualitas. Namun demikian secara terpisah dilihat dari masing-masing indikator maka ditemukan bahwa dari segi daya pembeda, pengecoh atau distraktor, validitas, dan reliabilitas tes pada umumnya sudah berfungsi dengan baik. Namun dilihat dari indikator tingkat kesukaran butir soal tidak baik.

\section{Simpulan dan Saran}

\section{Simpulan}

Berdasarkan hasil analisis butir soal tes ulangan akhir semester mata pelajaran matematika siswa kelas VII semester II di SMP Negeri 12 Kendari, dapat dikemukakan beberapa kesimpulan sebagai berikut:

1. Tingkat kesukaran setiap butir soal tes ulangan akhir semester mata pelajaran matematika siswa kelas VII semester II di SMP Negeri 12 Kendari tidak baik karena perbandingan antara soal mudah, sedang, dan sukar adalah $1: 6: 3$ atau $10 \%: 60 \%$ : $30 \%$ dimana dari 30 butir soal berisi komposisi soal mudah 3 butir soal, sedang 18 butir soal, dan sukar 9 butir soal. Ini menunjukkan bahwa tingkat kesukaran soal tersebut tidak baik bila mengacu pada standar yang ditetapkan Depdikbud yaitu 3 : $5: 2$ atau $30 \%: 50 \%: 20 \%$ yang dimana dari 30 butir soal seharusnya berisi komposisi soal mudah 9 butir soal, sedang 15 butir soal, dan sukar 6 butir soal.

2. Daya pembeda setiap butir soal tes ulangan akhir semester mata pelajaran matematika siswa kelas VII semester II di SMP Negeri 12 Kendari pada umumnya sudah termasuk baik kecuali butir soal nomor 3 dan 30 .

3. Pengecoh setiap butir soal tes ulangan akhir semester mata pelajaran matematika siswa kelas VII semester II di SMP Negeri 12 Kendari pada umumnya sudah berfungsi dengan baik kecuali butir soal nomor: 3 (Pengecoh D), 5 (Pengecoh A), 13 (Pengecoh A), 14 (Pengecoh D), 22 (Pengecoh A), dan 29 (Pengecoh D).

4. Validitas setiap butir soal tes ulangan akhir semester mata pelajaran matematika siswa kelas VII semester II di SMP Negeri 12 Kendari pada umumnya sudah baik kecuali butir soal nomor: 2, 3, 5, 12, dan 30 .

5. Besar reliabilitas tes ulangan akhir semester mata pelajaran matematika siswa kelas VII semester II di SMP Negeri 12 Kendari adalah 0,758 dengan derajat keterandalan termasuk kategori tinggi.

6. Besar kesalahan baku pengukuran tes ulangan akhir semester mata pelajaran matematika siswa kelas VII semester II di SMP Negeri 12 Kendari adalah 2.412. 
Dengan demikian berdasarkan indikator tingkat kesukaran, daya pembeda, pengecoh atau distraktor, validitas, reliabilitas, dan kesalahan baku pengukuran maka dapat disimpulkan bahwa tes ulangan akhir semester mata pelajaran matematika siswa kelas VII semester II di SMP Negeri 12 Kendari belum berkualitas.

\section{Saran}

Dari hasil penelitian, diketahui kualitas tes belum secara tepat mengukur kemampuan siswa di SMP Negeri 12 Kendari khususnya kelas VII, maka sangat disarankan untuk soal yang akan dibuat pada masa yang akan datang memperhatikan kriteria pembuatan soal yang baik terkait dengan soal Ulangan Akhir Semester, sehingga kualitasnya lebih baik dari sebelumnya. Perlu kiranya diadakan penelitian yang relevan yang berkelanjutan sehingga mutu pendidikan dapat terus dipantau dan dikendalikan, khususnya dalam bidang evaluasi yang memerlukan alat ukur yang berkualitas dalam proses pengukurannya.

\section{Daftar Pustaka}

Arikunto, Suharsimi. (2008). Dasar-Dasar Evaluasi Pendidikan. Jakarta : PT Bumi Aksara.

Cayo, Lasmi. (2011). Makalah Pengecoh Yang Baik Dalam Pilihan Ganda. Tersedia: http://lasmicayo.blogspot.co.id/2011/0 1/makalah-pengecoh-yang-baikdalam.html?m=1 (Diakses pada tanggal 24 April 2017).

Iman. (2013). Tes, Pengukuran, Penilaian, dan Evaluasi.

Tersedia: http://imankoekoeh.blogspot.co.id/201 3/12/tes-pengukuran-penilaian-danevaluasi.html (Diakses pada tanggal 14 April 2017).

Jayadi. (2005). Analisis Butir Soal Tes Bidang Studi Matematika Siswa Kelas II Semester II Tahun 2002/2003 di SMP Negeri 1 Andoolo Kabupaten Konawe Selatan (Skripsi: tidak Dipublikasikan). Kendari : Universitas Halu Oleo.

Jihad \& Haris A. (2012). Evaluasi Pebelajaran. Yogyakarta : Multi Presindo.
Minaltimay. (2010). Pengertian Tes dan Jenisjenis Tes. Tersedia: https://minaltimay.wordpress.com/201 0/12/16/pengertian-tes-jenis-jenis-tes/ (Diakses pada tanggal 14 April 2017).

Mudjijo. (1995). Tes Hasil Belajar. Jakarta: Bumi Aksara

Safari. (1993). Menyusun Soal yang Bermutu dalam Buletin Pengujian dan Penilaian. Jakarta: Pusat Penelitian dan Pengembangan Sistem Pengujian.

Sribanung. (2002). Identifikasi Kesulitan Siswa Dalam Memahami Materi Pelajaran Matematika Pada Pokok Bahasan Relasi dan Pemetaan Di Kelas II Cawu I SLTP Negeri 6 Kendari Tahun Ajaran 2000/2001 (Skripsi: tidak Dipublikasikan). Kendari : Universitas Halu Oleo.

Sudaryono. (2012). Dasar-Dasar Evaluasi Pembelajaran. Yogyakarta: Graha Ilmu.

Sukarja I.G.M.( 2002). Analisis Kesulitan Menyelesaikan Soal Cerita Pokok Bahasan Bilangan Bulat Siswa Kelas I Cawu I SLTP Negeri I Landono Kabupaten Kendari (Skripsi: tidak Dipublikasikan). Kendari : Universitas Halu Oleo.

Putrayasa, I.B. 2012. Buku Ajar: Landasan Pembelajaran. Program Studi Pendidikan Bahasa Indonesia Program Pasca Sarjana. Universitas Pendidikan Ganesha. Undiksha Press. Bali.

Rusman, 2016. Model-model Pembelajaran : Mengembangkan Profesionalisme Guru. Jakarta : Rajawali Pers.

Sanjaya, W. 2006. Kurikulum dan Pembelajaran Teori Praktik Pengembangan Kurikulum Tingkat Satuan Pendidikan (KTSP). Jakarta: Kencana Prenada Media Grup. 
Shadiq F, Amini NM. 2010. Pembelajaran

Matematika dengan Pendekatan

Realistik Di SMP. Modul

matematika SMP Program Bermutu.

Kemendiknas PPPPTK Matematika 2010 Yogyakarta.

Sugiyono. 2016. Metode Penelitian

Kuantitatif, Kualitatif, dan

Kombinasi (Mixed Methods).

Bandung: Alfabeta.

Zamsir \& Hasnawati. (2013). Model Diagnostik Kesulitan Belajar Siswa Berbasis Ujian Nasional. Jurnal Pendidikan Matematika, Vol 5 Nomor 1, hal 101102. 